\title{
AMS DATING OF HUMAN BONE FROM COVA DE LA PASTORA: NEW EVIDENCE OF RITUAL CONTINUITY IN THE PREHISTORY OF EASTERN SPAIN
}

\author{
Sarah B McClure ${ }^{1}$ Oreto García Puchol ${ }^{2}$ Brendan J Culleton ${ }^{3}$ \\ ABSTRACT. We present the results of 10 AMS radiocarbon dates for Cova de la Pastora (Alcoi, Alicante), a burial cave \\ attributed to the Late Neolithic/Chalcolithic in eastern Spain. The direct dating of 10 human mandibles from Cova de la Pas- \\ tora indicates that the cave was used as a burial place from the Late Neolithic/Chalcolithic to the Bronze Age. These dates \\ reveal a continuity of ritual use not previously identified at the site. This case also serves to highlight the utility of revisiting \\ historic excavations and museum collections with modern techniques to shed new light on the prehistoric human record.
}

\section{INTRODUCTION}

Cova de la Pastora is a relatively small limestone cave located in the interior mountainous valleys of the Autonomous Region of Valencia, near the city of Alcoi (Alicante), Spain (Figure 1). The prehistoric sequence has long been associated with funerary or ritual activities, particularly in the Late Neolithic (late 6th millennium cal BP). The site was excavated in 1940 by Vicente Pascual and again in 1945 and 1950 by Jose Alcácer of the Valencia Museum of Prehistory, and is one of over 130 known Late Neolithic and Chalcolithic burial caves in the region (Figure 1). In the course of excavations, numerous human remains were found in burials with large quantities of elaborate grave goods, consisting of jewelry (rings, bracelets, necklaces), finely made chert blades and points, polished stone axes, carved bone idols, and pottery. The human remains were of particular interest to scholars throughout Europe because it was the first time that trepanation was documented on the Iberian Peninsula and it was the greatest number of individuals buried collectively in the Valencian region.

Since the first publications (Ballester 1945, 1949), Cova de la Pastora became the point of reference for funerary customs during this period on the Mediterranean coast of the Iberian Peninsula. The rich assemblage of artifacts and human remains played a key role in reconstructions of Late Neolithic society and paralleled research on the emergence of social hierarchies in southeastern Spain (Los Millares). Artifacts made of non-local materials, such as the polished stone, cherts, variscite, ivory, and amber, testify to exchange within the Iberian Peninsula and areas as distant as northern Africa. Since its publication in 1949, however, the excavated materials have only been studied piecemeal (Rincón and Fenollosa 1949; Riquet 1953; Fusté 1957; Campillo 1976, 1977; Orozco 2000; Pascual 1998; Simón 1998; Soler 2002; Fregeiro 2006) and no radiocarbon dates are published.

Our reanalysis of museum collections and new excavation at the site indicate the complexity of prehistoric use of the cave. The original excavators kept diaries detailing their activities and associated finds that are housed in the Museum of Prehistory in Valencia. The first excavation campaign in 1940 unearthed the bulk of the burials. The excavator, Vicent Pascual, noted the relative locations of crania and the associated artifacts, precisely illustrating many of the grave goods (Figures 2, 3). However, analysis of excavation journals and comparison with museum holdings indicated that not all material recorded in the journals was deposited in the museum. Similarly, the excavators did not record everything with the same precision. Pascual's journal lists post-cranial human remains in the

\footnotetext{
${ }^{1}$ Department of Anthropology and Museum of Natural and Cultural History, University of Oregon, Eugene, Oregon 97403 USA. Corresponding author. Email: sbm@uoregon.edu.

${ }^{2}$ Departament de Prehistoria I Arqueología, Universitat de Valencia, Spain.

${ }^{3}$ Department of Anthropology, University of Oregon, Eugene, Oregon 97403, USA.
} 


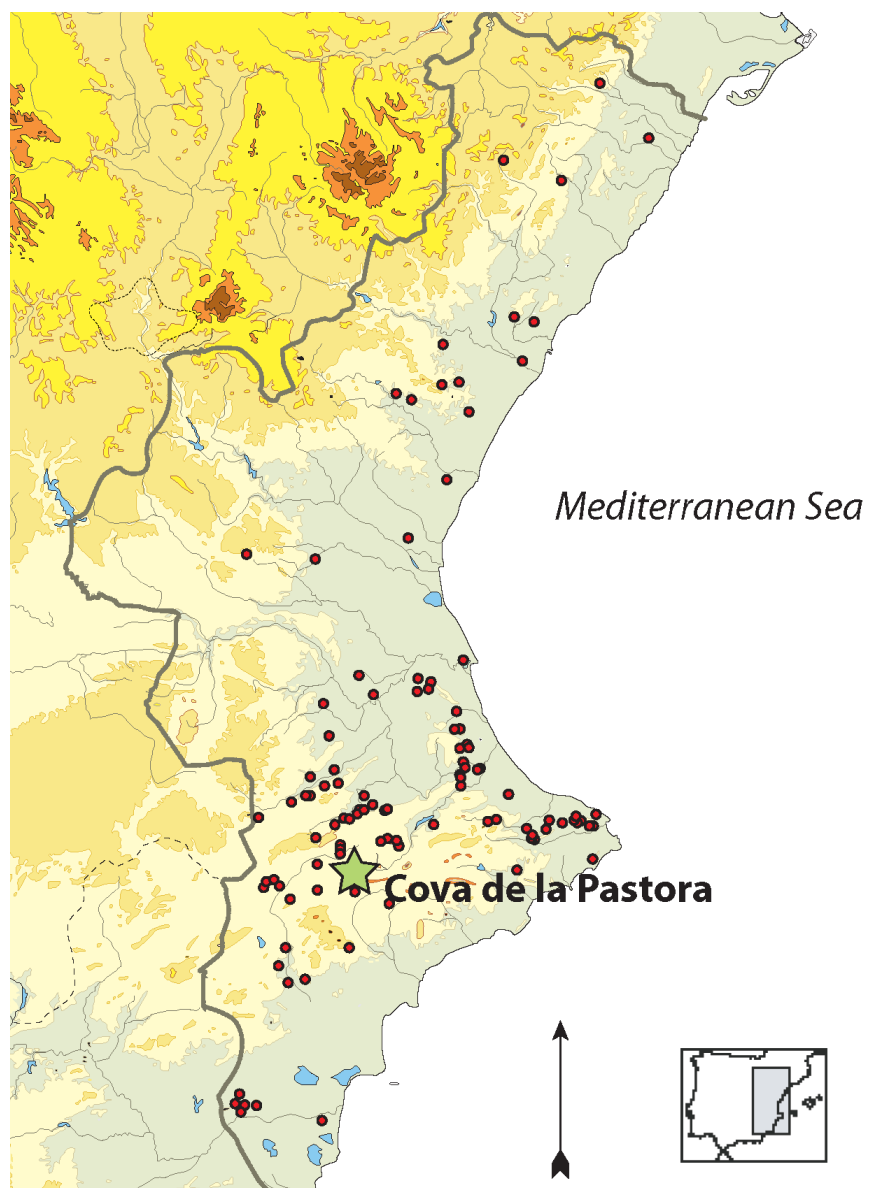

Figure 1 Location of Cova de la Pastora and distribution of Late Neolithic/ Chalcolithic burial caves in the provinces of Valencia and Alicante, Spain.

Cova de la Pastora: Aggregate Stratigraphic Profile of Crania Depths (after Pascual and Alcacer diaries)

Cranium

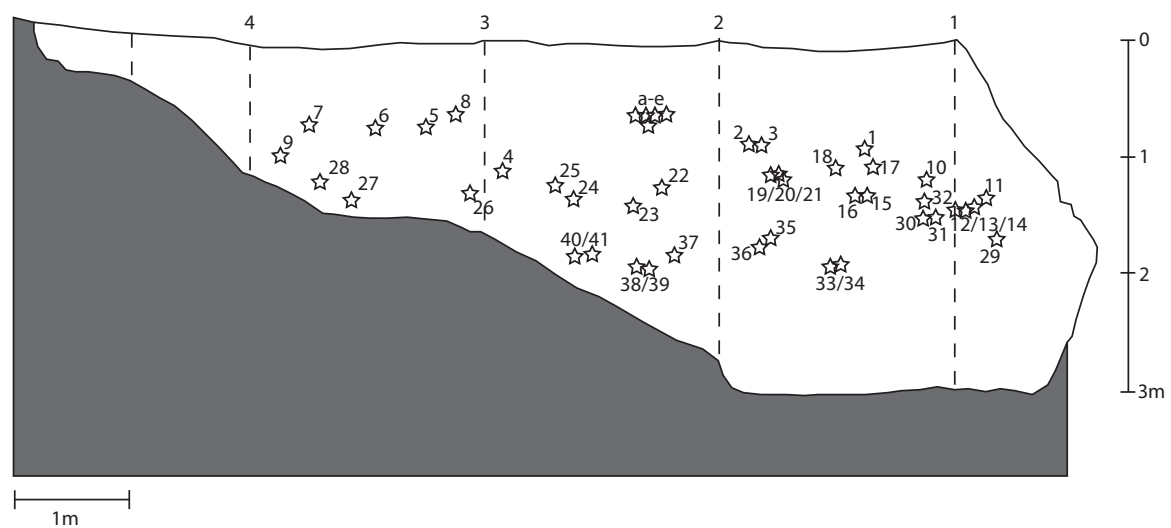

Figure 2 Reconstructed relative stratigraphy of human burials based on excavation journal by Vicente Pascual. Note that horizontal distribution is not accounted for in this representation. 


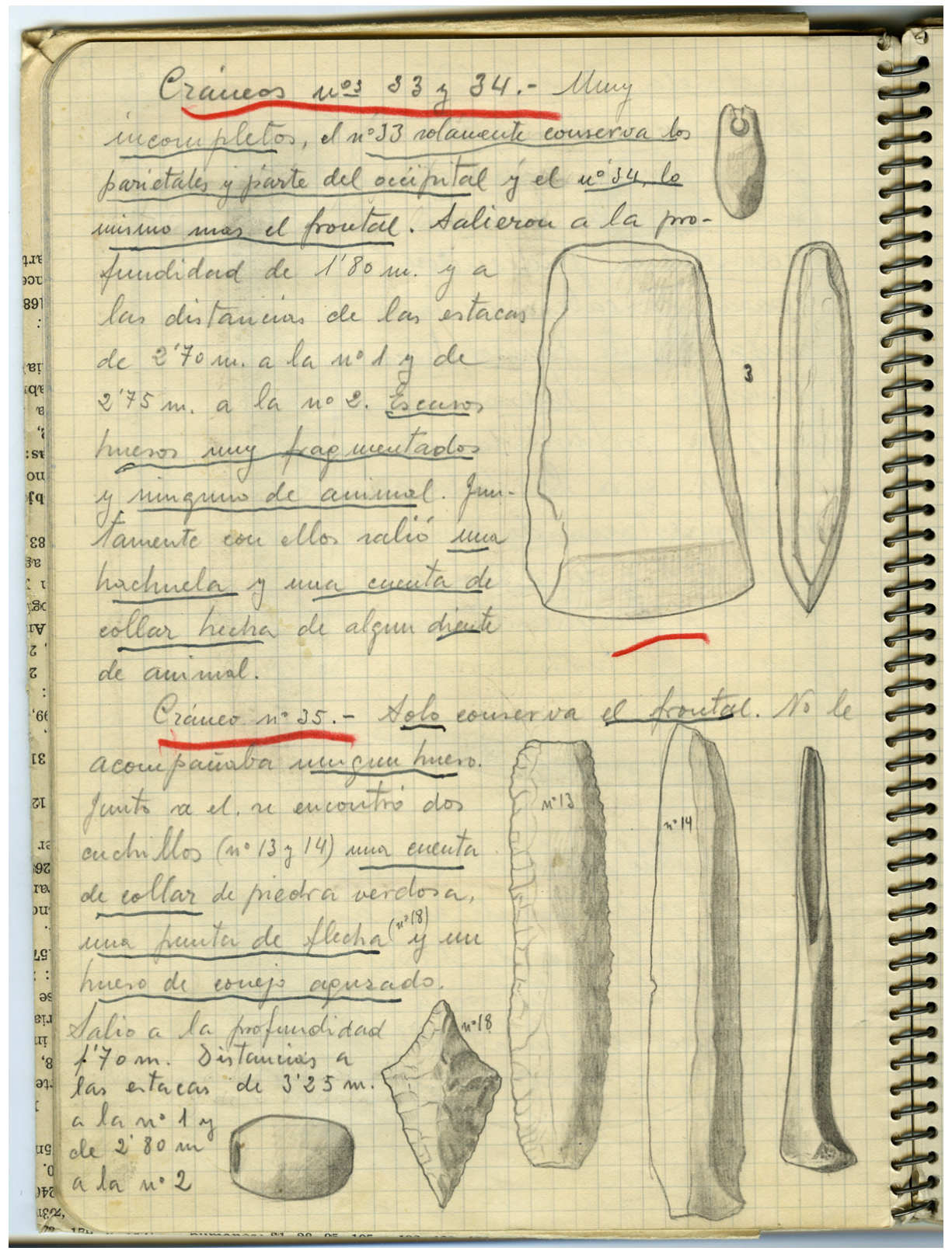

Figure 3 Sample of diary entry by Vicente Pascual

majority of burials; however, the museum holdings consisted of only crania and a small bag of postcranial bones. Similarly, faunal remains were mentioned more often in the diaries than the quantity of material in the museum could represent. The testing of back-dirt piles outside of Pastora Cave in 2008 revealed large quantities of post-cranial human remains and animal bones. Although the original excavators noted the presence of these remains, they were apparently not collected systematically. As a result, thousands of human and animal bone fragments recovered during the 2008 excavation are currently being studied. 
Artifacts from the Bronze Age and Iberian Iron Age are barely mentioned and insufficiently documented in the excavation diaries. In keeping with expectations of Late Neolithic burials from other sites - where 1 or 2 small bowls are recorded with a limited number of burials - the journals suggest that only small quantities of pottery were recovered. The diaries neglect to detail the large quantities (over 10,000 fragments) of Bronze Age and Iberian Iron Age pottery from the site. Furthermore, metal artifacts, including a Bell-Beaker period "palmela" point and other bronze personal adornment, are recorded but their implications were not discussed.

Based on the artifacts, Cova de la Pastora was used intermittently during the Late Neolithic, Bronze Age, Iron Age, and into historic times. However, the site remains a point of reference for Late Neolithic burial practices. By directly dating 10 individuals from the cave, we hoped to illuminate to what extent the use of the cave for burial was limited chronologically.

\section{SAMPLE SELECTION AND METHODS}

A minimum of 55 individuals were buried at Cova de la Pastora, although this number may rise as human remains from excavation in 2008 are analyzed (McClure et al. 2009). Since post-cranial skeletons were limited in the museum's assemblage, sampling was restricted to crania, many of which were in fragile condition. As a result, we chose to AMS ${ }^{14} \mathrm{C}$ date a series of 10 mandibles that had been separated from the crania. Sample selection was furthermore based on our intention to conduct several destructive analyses on single individuals, including ${ }^{14} \mathrm{C}$ dating, ancient DNA, and stable isotope analyses, requiring larger samples and a combination of bone and teeth from each individual. Since mandibles were not stored in association with their corresponding crania, we cannot reconstruct the precise location of these samples in the cave. It is unclear if the separation occurred after excavation or if they were not associated with specific crania, a common phenomenon in ossuaries where secondary or repeated burials can mix or disarticulate previous ones. Since the journals do not specify excavation of individual mandibles and several crania in the museum collection are missing mandibles, it is likely that the separation occurred after excavation. Given the degree of completeness of crania from the upper burials, it is likely that the sampled mandibles were from lower in the deposit. The 10 samples represent $18 \%$ of the known population in the cave.

Bone collagen for ${ }^{14} \mathrm{C}$ and stable isotope analyses was extracted and purified using the modified Longin method (Brown et al. 1988) following protocols of the UC Irvine Keck Carbon Cycle AMS Facility (UCI KCCAMS 2007). Bone samples were initially cleaned of adhering sediment and the exposed surfaces were removed by drilling or scraping with an X-acto ${ }^{\circledR}$ blade. Samples $(200$ $400 \mathrm{mg}$ ) were demineralized for $24-36 \mathrm{hr}$ in $0.5 \mathrm{~N} \mathrm{HCl}$ at $5{ }^{\circ} \mathrm{C}$ followed by a brief $(<1 \mathrm{hr})$ alkali bath in $0.1 \mathrm{~N} \mathrm{NaOH}$ at room temperature to remove humates. Collagen was rinsed to neutrality in multiple changes of distilled water $\left(\mathrm{DI} \mathrm{H}_{2} \mathrm{O}\right.$ ), and then gelatinized for $12 \mathrm{hr}$ at $70{ }^{\circ} \mathrm{C}$ in $0.01 \mathrm{~N} \mathrm{HCl}$. Gelatin solution was pipetted into precleaned Amicon Centriprep ${ }^{\circledR} 30$ ultrafilters (retaining $>30-\mathrm{kD}$ molecular weight collagen) and centrifuged 3 times for 30 min, diluted with distilled $\mathrm{H}_{2} \mathrm{O}$ and centrifuged 3 more times for $30 \mathrm{~min}$ to desalt the solution. Ultrafiltered collagen was lyophilized and weighed to determine percent yield.

The recognition that foreign carbon could be introduced to samples during ultrafiltration by humectants (e.g. glycerol, glycerin) or filter material (e.g. reconstituted cellulose, polyethersulfone) has spurred much recent methodological work to determine effective precleaning protocols (Bronk Ramsey et al. 2004; Higham et al. 2006; Brock et al. 2007; Hüls et al. 2007). To remove the glycerol coating from the Centriprep filters, the inner and outer portions of the filters were filled with $1 \mathrm{~N} \mathrm{HCl}$ and sonicated at $\sim 60^{\circ} \mathrm{C}$ for $1 \mathrm{hr}$ and rinsed with DI $\mathrm{H}_{2} \mathrm{O}$. DI $\mathrm{H}_{2} \mathrm{O}$ was centrifuged through the filters 
3 times for 30 min each, and the inner and outer portions were refilled with $\mathrm{DI}_{2} \mathrm{O}$ and sonicated for $1 \mathrm{hr}$ at $\sim 60^{\circ} \mathrm{C}$. After 3 further centrifuge runs with $\mathrm{DI} \mathrm{H}_{2} \mathrm{O}$, the filters were kept wet until use, no more than $48 \mathrm{hr}$ after precleaning. Results on Pleistocene and historic age bone standards processed along with the unknowns indicate no contamination from either modern or ancient carbon.

${ }^{14} \mathrm{C}$ samples $(\sim 2.5 \mathrm{mg})$ were combusted for $3 \mathrm{hr}$ at $900{ }^{\circ} \mathrm{C}$ in vacuum-sealed quartz tubes with $\mathrm{CuO}$ wire and $\mathrm{Ag}$ wire. At KCCAMS, sample $\mathrm{CO}_{2}$ was reduced to graphite at $550{ }^{\circ} \mathrm{C}$ using $\mathrm{H}_{2}$ and a $\mathrm{Fe}$ catalyst, with reaction water drawn off with $\mathrm{Mg}\left(\mathrm{ClO}_{4}\right)_{2}$ (Santos et al. 2004). Graphite samples were pressed into targets in $\mathrm{Al}$ boats and loaded on the target wheel for AMS analysis. ${ }^{14} \mathrm{C}$ ages were $\delta^{13} \mathrm{C}$-corrected for mass dependent fractionation with measured ${ }^{14} \mathrm{C} /{ }^{13} \mathrm{C}$ values (Stuiver and Polach 1977), and compared with samples of Pleistocene horse bone (background, $>48{ }^{14} \mathrm{C} \mathrm{kyr} \mathrm{BP}$ ), middle Holocene pinniped bone $\left(\sim 6500{ }^{14} \mathrm{C} \mathrm{BP}\right)$, late $\mathrm{AD} 1800$ s cow bone, and OX-1 oxalic acid standards for calibration. Stable isotope samples $(\sim 0.7 \mathrm{mg})$ were analyzed on a Fisons NA1500NC elemental analyzer/Finnigan Delta Plus isotope ratio mass spectrometer with a precision of $<0.1 \%$ for $\delta^{13} \mathrm{C}$ and $\delta^{15} \mathrm{~N}$.

\section{RESULTS AND DISCUSSION}

Table 1 and Figure 4 present the results and dates were calibrated with OxCal 4.1 (Bronk Ramsey 1995, 2001, 2009) using the IntCal04 curve (Reimer et al. 2004) as stable isotope values are consistent with a fully terrestrial diet. Good collagen preservation is indicated by $\mathrm{C}: \mathrm{N}$ ratios ranging from 3.22 to 3.34, consistent with values for modern collagen and an average $\mathrm{C}: \mathrm{N}$ of $3.29 \pm 0.27$ reported by Oxford ( $n=2146$; van Klinken 1999:691). Five dates (LPM14, LPM39, LPM23, LP3, LPM31) are statistically identical $\left(\chi^{2}=1.685, d f=4 ; p<0.05\right.$; Ward and Wilson 1978) and fall in the 30303350 cal BC range that is known as the Late Neolithic. Two dates (LPM31 and LPM17) lie between 2800 and 2900 cal BC in the Chalcolithic, and 1 date (LPM21) falls into the Bell Beaker Transition period (HCT) at 2461-2292 cal BC. Finally, 2 statistically identical dates (LP5; LPM6) are Bronze Age $\left(\chi^{2}=0.782, d f=1 ; p<0.05\right)$.

Table 1 AMS ${ }^{14} \mathrm{C}$ dates from Cova de la Pastora on human mandibles.

\begin{tabular}{llllllrl}
\hline UCIAMS\# & Sample ID & ${ }^{14} \mathrm{C}$ age & Error & $2 \sigma$ cal BC & $\delta^{13} \mathrm{C}(\% \mathrm{)})$ & $\delta^{15} \mathrm{~N}(\% \mathrm{)})$ & $\mathrm{C}: \mathrm{N}$ ratio \\
\hline 66309 & LPM14 & 4510 & 20 & $3347-3103$ & -19.5 & 9.0 & 3.26 \\
66314 & LPM39 & 4505 & 25 & $3347-3100$ & -19.0 & 10.0 & 3.26 \\
66312 & LPM23 & 4500 & 25 & $3346-3098$ & -19.1 & 9.7 & 3.27 \\
66305 & LP3 & 4480 & 20 & $3338-3039$ & -19.6 & 8.1 & 3.25 \\
66307 & LP9 & 4480 & 25 & $3339-3031$ & -19.5 & 9.5 & 3.29 \\
66313 & LPM31 & 4275 & 20 & $2913-2882$ & -19.3 & 9.7 & 3.24 \\
66310 & LPM17 & 4150 & 20 & $2874-2635$ & -19.3 & 10.6 & 3.34 \\
66311 & LPM21 & 3875 & 20 & $2461-2292$ & -19.6 & 9.5 & 3.34 \\
66306 & LP5 & 3515 & 20 & $1909-1759$ & -19.4 & 8.3 & 3.22 \\
66308 & LPM6 & 3490 & 20 & $1882-1752$ & -19.6 & 7.5 & 3.25 \\
\hline
\end{tabular}

The artifacts from Cova de la Pastora indicate that the burials date to the Late Neolithic. Prior to the Late Neolithic, people were buried in a multitude of ways: outside of habitation sites as well as in caves and rockshelters (Bernabeu et al. 2001). Beginning in the Late Neolithic, burials in caves became common in the Valencian region as well as in other regions of the Iberian Peninsula (e.g. Cantabria, Portuguese Estremadura). At the same time, collective burials were placed in megalithic tombs and mines in some other areas of the Iberian Peninsula (Ontañón 2003). The collective burials 


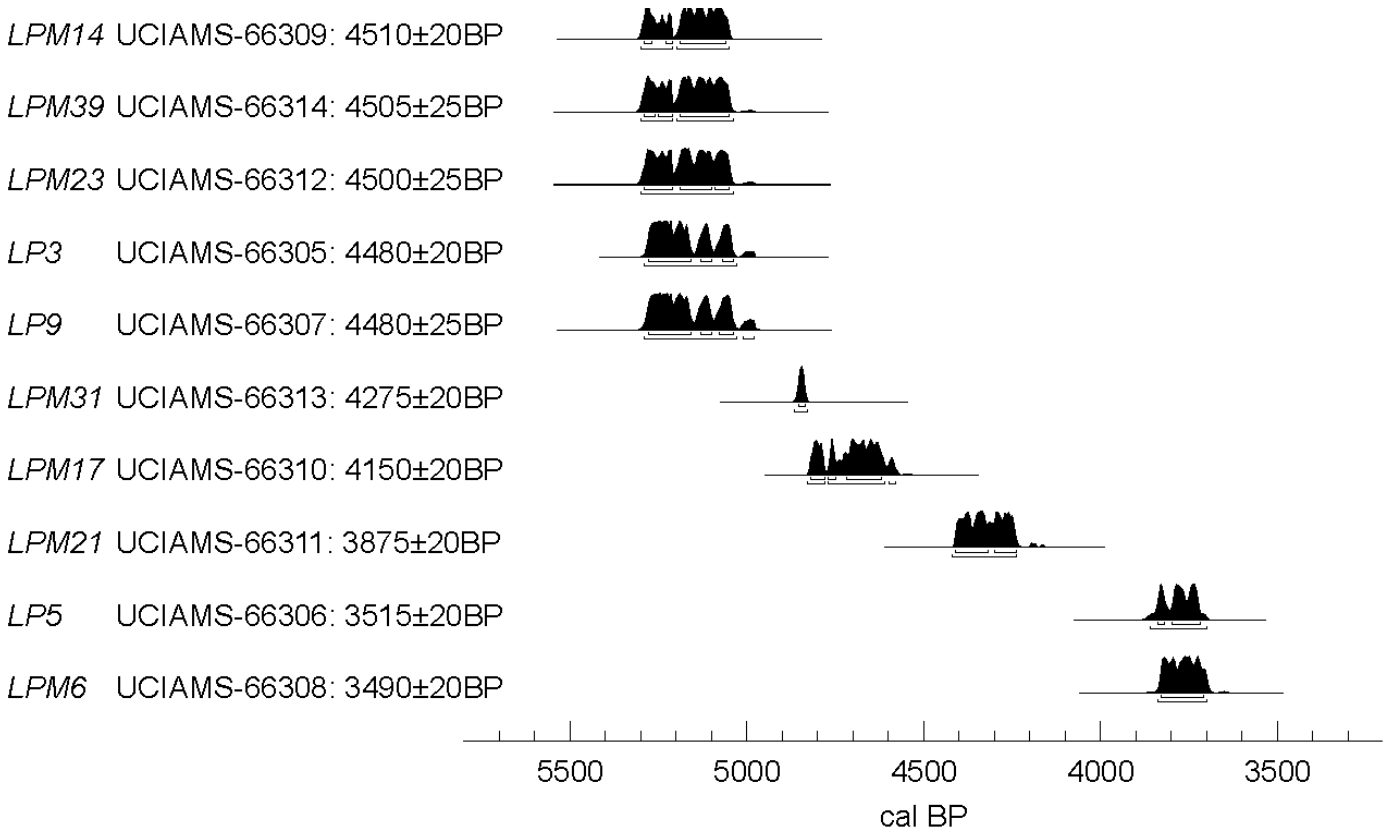

Figure 4 Calibrated probability distributions for dates from Cova de la Pastora

in caves often take on the character of an ossuary, where the space is reused and reorganized through time (Soler 2002). Objects in the graves are common throughout the region and consist of personal ornaments (e.g. beads made of a variety of stones, shell, and bone), daily items (e.g. ceramic vessels, chert points and blades, polished stone), and ritual items such as different types of carved bone idols. This suite of artifacts appears to repeat a basic grave good tradition. However, clear patterns of burial goods are not documented until the Bell Beaker period, when a number of burials with associated grave good assemblages are documented. Although the Late Neolithic artifacts from Cova de la Pastora suggest a common suite of grave goods for individuals, the lack of clear associations limits their interpretive potential. Since many of the excavations at burial caves date to the early 20th century, the excavation techniques do not conform to modern expectations of systematic analyses.

The suite of dates from Cova de la Pastora provides tentative evidence that the rate of interment may have shifted during the period of use as a burial site. The dates of the 5 individuals in the late 3rd millennium $\mathrm{BC}$ indicate that these people were buried in relatively quick succession. It is likely that this is a time span that allowed traditions to be transmitted between generations, and it is possible that these burials occurred within the span of human memory of the participants. The later dates indicate that this burial custom continued, but perhaps not in as rapid succession as the earlier phases. The artifacts are not chronologically sensitive enough to mirror various phases within the Late Neolithic.

The phenomenon of multiple inhumations in caves is common for the Late Neolithic/Chalcolithic in the region of Valencia. However, burial customs are more diverse during the Bell Beaker phase and the Bronze Age (see Rojo-Guerra et al. 2005). Recent excavations indicate that during the Bell Beaker phase, dispersed individual pit graves were placed inside villages. Specific grave goods (including Bell Beaker vessels and bronze artifacts) accompanied these inhumations. Caves continued to be used as funerary sites during this period, although the specific contexts, rate of deposition, and characteristics remain elusive (Martí et al. 1995; Juan Cabanilles 2005). Metal objects, primarily bronze 
or copper wires and platelets, are typical of later periods and first appear during the Bell Beaker phase. In the absence of distinct burials, these objects are difficult to identify specifically as grave goods, and are not distinctive to sex or specific individuals. The identification of the metal artifacts as grave goods from Cova de la Pastora was not straightforward, and they were not found in clear association with specific burials. As a result, the ${ }^{14} \mathrm{C}$ date falling into the Bell Beaker phase is of particular interest. This date came as a surprise because although a bronze "palmela" point is known from the site, it is the only identified artifact from this period.

Inhumation burials in caves and rockshelters are also known from the Early and Middle Bronze Age, but they coexist with inhumations in habitation sites including the interiors of living spaces (Soler et al. 1999). In the case of Cova de la Pastora, Late Bronze Age use of the site was known previously, documented primarily through pottery (Soler 2002). Although it is unclear what the primary purpose was, numerous large storage vessels indicated that the cave could have been used as cold storage. The 2 dated individuals from the Middle Bronze Age now confirm use as a burial place. This result was also surprising, since clear evidence of burial use during this period was not indicated by the recovered artifacts.

The ${ }^{14} \mathrm{C}$ dates from Cova de la Pastora have opened up new avenues of interpretation for a site that has played a leading role in Valencian prehistory for over $70 \mathrm{yr}$. Our analysis found that individuals were buried in the cave over 2 millennia, providing evidence of a continuation of ritual practice through differing social and economic contexts. Although the precise nature of this ritual remains elusive, the ${ }^{14} \mathrm{C}$ dates presented indicate a long-term use of the cave as a burial ground, and hint at changes in the rate of use during the Late Neolithic/Chalcolithic. Continued analysis on the human remains and grave goods found at the site will no doubt further our understanding of the role of Cova de la Pastora in Valencian prehistory. As it stands, the ${ }^{14} \mathrm{C}$ dates have surpassed expectations and broadened our knowledge about ritual activities in the prehistoric past.

\section{ACKNOWLEDGMENTS}

Fieldwork and laboratory analyses were supported by the National Geographic Society (Grant \#8281-07), the National Science Foundation (OISE-0701241; GRFP-2006022778), the University of Valencia, the University of Oregon, the Museo de Prehistória Valencia, Servicio de Investigación Prehistórica, and the Museu Arqueologic Municipal Camil Visedo Moltó, Alcoi. We are grateful to Helena Bonet, Bernat Martí, Josep M Segura, Maria Jesus de Pedro, Albert Sanchez, and Consuelo de la Roca for support and assistance in sample selection. Special thanks to Dale Guthrie, Douglas Kennett, and Pat O'Grady for providing bone samples used as standards in this study, and to John Southon and Will Beaumont at KCCAMS for generously sharing their analytical expertise and giving patient advice on all aspects of the dating program.

\section{REFERENCES}

Ballester Tormo I. 1945. Idolos oculados valencianos. Archivo de Prehistoria Levantina II:115-41.

Ballester Tormo I. 1949. La Labor del SIP y su Museo en los años 1940-1948. Valencia: SIP.

Bernabeu Auban J, Molina Balaguer Ll, Garcia Puchol O. 2001. El mundo funerario en el horizonte cardial valenciano. Un registro oculto. Saguntum (PLAV) 33: 27-36.

Brock F, Bronk Ramsey C, Higham T. 2007. Quality assurance of ultrafiltered bone dating. Radiocarbon 49(2):187-92.
Bronk Ramsey C. 1995. Radiocarbon calibration and analysis of stratigraphy: the OxCal program. Radiocarbon 37(2):425-30.

Bronk Ramsey C. 2001. Development of the radiocarbon calibration program. Radiocarbon 43(2A):355-63.

Bronk Ramsey C. 2009. Bayesian analysis of radiocarbon dates. Radiocarbon 51(1):337-60.

Bronk Ramsey C, Higham T, Bowles A, Hedges R. 2004. Improvements to the pretreatment of bone at Oxford. Radiocarbon 46(1):155-63.

Brown TA, Nelson DE, Vogel JS, Southon JR. 1988. Im- 
proved collagen extraction by modified Longin method. Radiocarbon 30(2):171-7.

Campillo Valero D. 1976. Lesiones Patológicas en Cráneos Prehistóricos de la Región Valenciana. Valencia: Diputación de Valencia.

Campillo Valero D. 1977. Paleopatología del Cráneo en Cataluña, Valencia y Baleares. Barcelona.

Fregeiro MI. 2006. Investigaciones antropológicas sobre el Calcolítico peninsular y estudio bioarqueológico de 'la Cova de la Pastora' (Alcoy, Alicante). In: Sanahuja ME, editor. Contra la Falsificación del Pasado Prehistórico. Buscando la realidad de las mujeres y los hombres detrás de los estereotipos. Ministerio de Trabajo y Asuntos Sociales: Instituto de la Mujer. p 188310.

Fusté Ara M. 1957. Estudio antropológico de los pobladores neo-eneolíticos de la Región Valenciana. Valencia: SIP.

Higham TFG, Jacobi RM, Bronk Ramsey C. 2006. AMS radiocarbon dating of ancient bone using ultrafiltration. Radiocarbon 48(2):179-95.

Hüls MC, Grootes PM, Nadeau M-J. 2007. How clean is ultrafiltration cleaning of bone collagen? Radiocarbon 49(2): 193-200.

Juan Cabanilles J. 2005. The Beaker manifestations in the Valencian Country. a synthesis. In: Rojo MA, Garrido R, García I, editors. Bell Beakers in the Iberian Peninsula and their European Context. Valladolid: Universidad de Valladolid. p 401-9.

Martí B, De Pedro MJ, Enguix R. 1995. La Muntanya Assolada de Alzira y las necrópolis de la cultura del Bronce Valenciano. Saguntum PLAV 28:72-92.

McClure SB, García O, Roca de Togores C, Culleton B, Haber M. 2009. Chalcolithic burials: new evidence from Cova de la Pastora, Spain. Poster presented at the 74th Annual Meeting of the Society for American Archaeology, Atlanta, Georgia.

Ontañón Peredo R. 2003. Caminos hacia la Complejidad: El Calcolítico en la Region Cantábrica. Santander: Servicio de Publicaciones de la Universidad de Cantabria.

Orozco Koehler T. 2000. Aprovisionamiento e Intercambio. Análisis Petrológico del Utilaje Pulimentado en la Prehistoria Reciente del País Valenciano (España). Oxford: BAR International Series 867.

Pascual Benito JL1. 1998. Utilaje Oseo, Adornos e Idolos Oculados Valencianos. Valencia: Diputación de Valencia.

Reimer PJ, Baillie MGL, Bard E, Bayliss A, Beck JW,
Bertrand CJH, Blackwell PG, Buck CE, Burr GS, Cutler KB, Damon PE, Edwards RL, Fairbanks RG, Friedrich M, Guilderson TP, Hogg AG, Hughen KA, Kromer B, McCormac G, Manning S, Bronk Ramsey C, Reimer RW, Remmele S, Southon JR, Stuiver M, Talamo S, Taylor FW, van der Plicht J, Weyhenmeyer CE. 2004. IntCal04 terrestrial radiocarbon age calibration, 0-26 cal kyr BP. Radiocarbon 46(3):1029-58.

Rincón de Arellano A, Fenollosa J. 1949. Algunas consideraciones acerca de los cráneos trepanados de la Cova de la Pastora (Alcoy). La Labor del SIP y su Museo en los años 1940-1948:66-76.

Riquet R. 1953. Analyse anthropologique des crânes énéolithiques de la grotte sépulcrale de La Pastora. $A r$ chivo de Prehistoria Levantina IV:105-22.

Rojo-Guerra MA, Garrido-Peno R, García-Martínez de Lagrán I, editors. 2005. El Campaniforme en la Península Ibérica y su Contexto Europeo/Bell Beakers in the Iberian Peninsula and their European Context. Valladolid: Universidad de Valladolid.

Santos GM, Southon JR, Druffel-Rodriguez KC, Griffin S, Mazon M. 2004. Magnesium perchlorate as an alternative water trap in AMS graphite sample preparation: a report on sample preparation at the KCCAMS Facility at the University of California, Irvine. Radiocarbon 46(1):165-73.

Simón García JL. 1998. La Metalurgia Prehistórica Valenciana. Valencia: Diputación de Valencia.

Soler Diaz JA. 2002. Cuevas de Inhumación Multiple en la Comunidad Valenciana. Madrid/Alicante: Real Academia de la Hisotria y Museo Arqueológico Provincial de Alicante.

Soler Diaz JA, Ferrer C, González P, Belmonte D, López JA, Iborra P, Cloquell B, Roca de Togores C, Chiarri J, Rodes F, Martí JB. 1999. Uso funerario al final de la Edad del Bronce de la Cova d'En Pardo, Planes, Alicante. Una perspectiva pluridisciplinar. Recerques del Museu d'Alcoi 8:111-77.

Stuiver M, Polach HA. 1977. Discussion: reporting of ${ }^{14} \mathrm{C}$ data. Radiocarbon 19(3):355-63.

van Klinken GJ. 1999. Bone collagen quality indicators for paleodietary and radiocarbon measurements. Journal of Archaeological Sciences 26(6):687-95.

Ward GK, Wilson SR. 1978. Procedures for combining radiocarbon age determinations: a critique. Archaeometry 20(1):19-31.

UCI KCCAMS. 2007. Chemical pretreatment for bone: ultrafiltration method. Manuscript available online: http://www.ess.uci.edu/ dossantos/. 